\title{
Article
}

\section{Risk Information in Non-Financial Disclosure}

\author{
Justyna Fijałkowska 1,2 (D) and Dominika Hadro 2,3,*(D)
}

1 Department of Finance and Accounting, University of Social Sciences, 90-113 Lodz, Poland; jfijalkowska@san.edu.pl

2 Management Department, University of Turin, Bis, 10134 Turin, Italy

3 Department of Finance, Wroclaw University of Economics and Business, 53-345 Wroclaw, Poland

* Correspondence: dominika.hadro@ue.wroc.pl

check for updates

Citation: Fijałkowska, Justyna, and Dominika Hadro. 2022. Risk

Information in Non-Financial

Disclosure. Risks 10: 11. https://

doi.org/10.3390/risks10010011

Academic Editors: Elżbieta

Szczepankiewicz and

Beata Zyznarska-Dworczak

Received: 31 October 2021

Accepted: 21 December 2021

Published: 3 January 2022

Publisher's Note: MDPI stays neutral with regard to jurisdictional claims in published maps and institutional affiliations.

Copyright: (c) 2021 by the authors Licensee MDPI, Basel, Switzerland. This article is an open access article distributed under the terms and conditions of the Creative Commons Attribution (CC BY) license (https:// creativecommons.org/licenses/by/ $4.0 /)$.

\begin{abstract}
This paper aims to research the topics related to risk included in non-financial disclosure (NFD) of companies listed on the Warsaw Stock Exchange (WSE) and explore factors that influence the risk topics ratio in NFD. We applied a content analysis using topic modeling to discover latent risk topics in NFD. Next, with Ward's clustering, we identified four groups of companies with a homogenous risk topic mixture. For causal analysis, to explain the differences in risk topics ratio, we used qualitative comparative analysis (QCA), which allowed us to obtain three paths (variable configurations) leading to the high ratio of risk topics in NFD. Our results suggest that companies disclosing risk information extensively in their NFDs concentrate almost solely on social risk matters. In contrast, companies talking briefly about environmental and social (E\&S) risk prepare their NFDs with a more balanced distribution of E\&S topics and their financial implication. In general, the companies' exposure to E\&S risk and the use of NFD standards and guidelines as well as the type of NFD impact the space dedicated to risk information. This paper contributes to academics and regulators, filling the gap about risk disclosure in the NFD, identifying the nature of corporate risk disclosures, and upgrading research about determinants of risk information in non-financial disclosure.
\end{abstract}

Keywords: risk; disclosure; non-financial; topic modeling; QCA

\section{Introduction}

The fast-changing environments, globalization, and the improvement of information technologies made corporate risk a highly relevant issue in management and accounting (Serrasqueiro and Mineiro 2018). Moreover, several accounting scandals and the latest financial crisis have emphasized the prominence of the risk disclosure topic (e.g., Elshandidy et al. 2018b; Singleton-Green 2012; Pérignon and Smith 2010). The aftermath analysis of financial crises indicates their association with insufficient information on risk and uncertainties (Barth and Landsman 2010). Since then, as a response to pressure from regulators (Leopizzi et al. 2020; Bravo 2017) and also to meet other stakeholders' information needs, companies augmented their risk reporting or risk disclosure (Jorgensen and Kirschenheiter 2003). Accurate identification of the nature and scope of the possible risk allows taking appropriate measures to reduce it at the right time (Szczepankiewicz 2011). Usually, all kinds of stakeholders expect disclosure transparency and accountability of their companies (Fijałkowska and Zyznarska-Dworczak 2018). Capital markets are more and more demanding in relation to information quantity, but especially to its quality. Providing truthful, material, and relevant information becomes critical for markets' proper functioning, e.g., for an appropriate evaluation of investments based on apposite information concerning companies' risk profiles (Linsley and Shrives 2006). Risk disclosure is considered increasingly significant to improve transparency and reinforce the market discipline (Abraham and Shrives 2014; Ahmed et al. 2004; Beretta and Bozzolan 2004; Cabedo and Tirado 2004; Linsley and Lawrence 2007; Linsley and Shrives 2006; Linsley et al. 2008; 
Schrand and Elliott 1998). Additionally, as is underlined by Bartoszewicz and RutkowskaZiarko (2021), "the concept of sustainable development, which has become widespread in the past years, as well as the changing environment and business model, have popularised the trend among socially responsible companies to disclose non-financial information". As a consequence, non-financial disclosure should also refer to risk concerning the social and environmental engagement of companies.

Accounting and finance academics have recognized a gap between actual and required information caused by the accounting frameworks and their mismatch to properly capture, measure, and report the uncertainties and risks businesses face. That gap meaningfully impedes stakeholders to make the right decisions (Magnan and Markarian 2011). Even though in recent decades there was an upsurge of research about corporate risk disclosure, it referred mainly to financial reporting (Abraham and Cox 2007; Allini et al. 2016; Linsley and Shrives 2006; Elzahar and Hussainey 2012; Bao and Datta 2014; Campbell et al. 2014; Hope et al. 2016). Although annual reports are understood as the primary source of information for decision making (Solomon et al. 2000), and therefore they are also intended to play a significant role in the disclosure of the risk information faced by companies, most research highlights their insufficiency. In general, communication about risk relates to two broad categories of risks for firms: (i) business risk (financial risk) that concerns the shareholders and their firm and (ii) social and environmental risks (non-financial risk) that concern the business stakeholders of the firm. Risk information, as presented in financial disclosure, concerning business risk, has its relevant limitation (Kravet and Muslu 2013). It is claimed to generate doubts about its completeness and, in consequence, about the quality and usefulness of disclosed risk information (Abraham and Shrives 2014). Risk disclosure in annual reports tends to be mainly qualitative, retrospective, and often presents boilerplate risk information (Lajili and Zéghal 2005; Linsley and Shrives 2006; Linsley and Lawrence 2007; Oliveira et al. 2011; Abraham and Shrives 2014). Therefore, risk reporting in annual reports is inadequate as the level of disclosure is consistently low (Tirado-Beltrán et al. 2020), specifically for non-financial risks. The companies and regulators disclosing risk information are inclined towards paying more consideration to financial risk disclosure, which has been subject to numerous regulations. Their complexity, however, further contributes to the unsatisfactory level of risk disclosure in annual reports (Elshandidy et al. 2018a). The adequacy of such risk disclosure in meeting users' information needs is questionable (Linsley and Shrives 2006; Steyn 2014; Moolman et al. 2016). An additional issue is that while concentrating merely on financial business risk, traditional financial reports ignore other types of risk that are a threat to organizational sustainability and society more broadly (Guthrie et al. 2020). In particular, it relates to the second category of risk that is non-financial and refers to a social and environmental one. As non-financial risk management is useful to achieve corporate responsibility and social responsibility goals (Wong 2013), this type of risk should be disclosed, whereas it is the financial risk information that is usually the most frequently published (Beretta and Bozzolan 2004; Lajili and Zéghal 2005; Linsley and Shrives 2005). Consequently, more studies concerning other types of risks and risk disclosure other than in financial reports are needed.

Hence, in this study, we focus on the risk information in non-financial disclosure. Already in 1987, the Report of the Task Force on Risk and Uncertainties (AICPA 1987), followed by the Jenkins Report (AICPA 1994), pioneered the demand for qualitative and prospective information that would comprise the foremost risks and uncertainties faced by businesses. Todays' initiatives of the Global Reporting Initiative (GRI), International Integrated Reporting Framework (IIRF) Board, and European Union issuing a new Directive (2014/95/EU) (the Directive) also validate and reinforce the relevance of the need to broaden the scope of non-financial disclosures in terms of risk reporting. Following the initiatives of these bodies, with the introduction of the Directive and the spread of the reporting on social and governance themes (Steurer 2010, 2015), non-financial reporting became potentially an important source of information, also supplementing traditional annual statements in the context of risk disclosure, especially in terms of non-financial risk. 
Non-financial reporting is defined as a type of disclosure not based on typical financial data. Nevertheless, it provides stakeholders with an understanding of significant areas of value creation within a company that goes far beyond financial statements (Hirschi 2021). It also has an important role in an organization to mitigate threats and reduce the legitimacy gap (Chen et al. 2008; Deegan et al. 2002; Deegan 2002). According to legitimacy theory, an organization's top management is held responsible for identifying the legitimacy gap and applying the necessary social practices and then disclosing its activities to stakeholders, to safeguard accountability (Venturelli et al. 2019). While analyzing non-financial disclosure, stakeholders expect to find out how a company is exposed to and manages risks and opportunities linked to climate, natural resource scarcity, pollution, waste, and other environmental factors and the impact that a company has on the environment and climate (Deloitte 2021). Non-financial disclosure should provide investors and other stakeholders with adequate transparency about risk exposure and an approach to managing risks and opportunities. Investors pursue useful and trustworthy risk information to determine all risks faced by companies in their decision-making process (Miihkinen 2013; Cole and Jones 2004; Linsmeier et al. 2002; Rajgopal 1999; Venkatachalam 1996) Incoherent risk disclosures can affect investment decision making and result in a loss burden for investors (Tan et al. 2017; Abdullah et al. 2015; Lajili and Zéghal 2005).

The existing studies in the area focus mainly on the quantity of the information disclosed (Shivaani et al. 2019; Jia et al. 2016) rather than on the determinants of this disclosure. Moreover, while the mainstream literature on risk disclosure continues to focus on traditional annual reports, to date there is a lack of research on risk in non-financial disclosure. (Guthrie et al. 2020). The disclosure of non-financial risks has been scarcely investigated (Elshandidy et al. 2018b). In this paper, we try to contribute to this still lacking field of research. We also answer the call of Beretta and Bozzolan (2004) stating that not only the amount of information disclosed but also the issues relating to "what information is disclosed" should be analyzed in future research.

The aim of our study is two-fold. We research what are the topics related to risk included in non-financial disclosure (NFD) of companies listed on the Warsaw Stock Exchange. The second aim is to understand what are the determinants of this disclosure, checking the set of factors that influenced the risk topics ratio in NFD of analyzed companies.

In this study, we apply a content analysis using topic modeling, a machine learning technique to discover latent risk topics in NFD available in 2018-one year after implementing the Directive 2014/95/UE. Next, with Ward's clustering, we identify four groups of companies with a homogenous risk topic mixture. For causal analysis, to explain the differences in risk topics ratio among WSE companies, we use qualitative comparative analysis (QCA), which allows us to obtain three paths (variable configurations) leading to the high ratio of risk topics in NFD. The results of our research indicate that companies disclosing risk information extensively in their NFDs concentrate almost solely on social risk matters. In contrast, companies talking briefly about ESG risk prepare their NFDs with a more balanced distribution of environmental and social topics together with their financial implication. In general, the companies' exposure to E\&S risk, the use of NFD standards, and the type of NFD impact the space dedicated to risk information.

We believe that our research on risk disclosure practices in non-financial reporting gives a more complete picture of the state of the art of voluntary engagement of companies in this field and, at the same time, it benefits standard setters and regulators in the further development of guidelines and standards. We contribute to the existing research on risk disclosure by offering new evidence on the extent to which, and how, merging the accounting numbers examined extensively in earlier studies with non-accounting information (i.e., non-financial risk information) is instrumental in reflecting a more holistic picture of corporate risk. Our paper also advances prior research on the determinants of risk disclosure. By doing so, we respond Lyle et al.'s (2013) call for empirical research to study 
the importance of non-financial disclosure, also in the field of risk disclosure expressed by Beretta and Bozzolan (2004).

Our paper is structured as follows. Section 2 discusses relevant literature review underpinnings and develops research questions. Section 3 provides the research methods. Empirical results and further analyses are discussed in Section 4. Section 5 concludes, provides implications, and suggests avenues for future research.

\section{Literature Review}

\subsection{Risk Disclosure-Motives, Usefulness, and Determinants}

Since risk is part of the decision-making process, it requires explicit recognition, identification, monitoring, and management (Fraczkiewicz-Wronka et al. 2021). This all should be crowned by adequate disclosure of risk information. In the last decade, many shortcomings have been highlighted in systemic risk monitoring, due to the global financial crisis, followed by the European debt crisis, the subsequent economic stagnation, and the current pandemic, (Dziwok and Karaś 2021), and its disclosure. Risk disclosure has been defined by prior literature as information about any opportunity, prospect, hazard, danger, harm, threat, or exposure that has or could affect the company in the future (Linsley and Shrives 2006).

Risk requires continual communication (e.g., Jackson 2021). The complexity and controversial nature of the regulation of risk reporting practices, as well as the regulations themselves, have played a central role in the emergence of an extensive and growing literature on risk reporting (Elshandidy et al. 2018b). Prior risk disclosure literature largely focuses on three aspects: the first concerns exploring the underlying drivers and motivations of risk disclosure, the second relates to the examination of the usefulness of such disclosure (for the latest review, see Elshandidy et al. 2018b), and the third focuses on the determinants of risk disclosure.

The theoretical perspective from which the motives, utility, and determinants of risk disclosure are discussed varies among authors (Oliveira et al. 2011). We may expect that managers, motivated by legitimacy incentives, tend to disclose mainly risk information with positive impact (good news). The incentives for risk information with negative impact (bad news) may be caused by the will to exempt managers from responsibilities as set by attribution theory or by impression management theory (Merkl-Davies et al. 2011). The interconnection between financial distress (risk) and information disclosure is an ongoing important and promising area of research (Lukason and Camacho-Miñano 2019). Researchers generally find that companies have a motive to disclose risk information as it benefits investors, enabling companies to better allocate resources. Measuring and managing financial risk represent key concerns of investors (Sheraz and Nasir 2021). Therefore, within the current environment, the motivation concerning risk disclosure is determined by the circumstances in which risk disclosure is important, specifically when the risk level of investment is high (Abraham and Cox 2007; Linsley and Shrives 2006), entailing pressure on companies to attract financial analysts (Sundgren et al. 2018; Lehavy et al. 2011), investors, and professionals (Abraham and Shrives 2014). Moreover, in today's world, organizations that operate under rapidly changing environments are becoming more exposed to unpredicted situations (Bakos and Dumitrașcu 2021). In these conditions, companies are more eager to disclose information concerning risk. The motivation to disclose risk information may also be dictated by the potential usefulness that has been widely analyzed by prior research (e.g., Cole and Jones 2004; Linsmeier et al. 2002; Rajgopal 1999; Venkatachalam 1996). Following proprietary cost theory to conceptualize reporting attitudes towards the cost and benefits of risk disclosure, some scholars indicated the potential positive market response to this information (Verrecchia 1983; Healy and Palepu 2001; Abraham and Shrives 2014; Leopizzi et al. 2020). Several previous studies have investigated the impact of risk disclosure on market indicators in the US, including market liquidity, as in Campbell et al. (2014), investor-perceived risk, as in Kravet and Muslu (2013), and the reduction in the cost of capital (Heinle and Smith 2017). Analyzing risk disclosure through 
the lens of stakeholder theory, the links between companies and their stakeholders can be explored, which include understanding how organizations respond to stakeholder expectations for information on risks and opportunities (Deegan 2000). Following this theory, the success of the organization relies upon its ability to manage and balance relationships with stakeholders by providing satisfactory disclosure on both financial and non-financial topics (Gray et al. 1995; García-Sánchez et al. 2013). Sound risk disclosure's main benefit for companies is, therefore, the reduction in information asymmetries (Deumes 2008; Deumes and Knechel 2008; ICAEW 2011; Linsley and Shrives 2000, 2005, 2006; Schrand and Elliott 1998; Solomon et al. 2000). Reducing information asymmetry through sound risk disclosure potentially leads to better allocation of capital in markets, increased transparency, and the consequent enhancement of economic efficiency (Serrasqueiro and Mineiro 2018). There are also, however, incentives to avoid risk disclosure, concerning mainly the cost of information preparation (Deumes and Knechel 2008; Solomon and Cooper 1990), together with the threat of litigation and loss of reputation (Deumes and Knechel 2008). Inconsistent risk disclosure, in fact, can affect the investment decision-making process and can bring the burden of losses to investors (Tan et al. 2017; Abdullah et al. 2015; Lajili and Zéghal 2005). Some risk information might be deliberately withheld to protect the managers' interest (Abraham and Shrives 2014).

The third, main field of research concerning risk disclosure refers to its determinants that have been widely analyzed in the prior literature (e.g., Atan et al. 2010; Abraham and Cox 2007; Beretta and Bozzolan 2004; Linsley and Shrives 2006; Lajili and Zéghal 2005; Rajab and Schachler 2009; Vandemaele et al. 2009; Dobler et al. 2011; Oliveira et al. 2011; Allini et al. 2016; Elamer et al. 2019). These studies usually find that risk disclosure is qualitative and often underline the vagueness of information disclosed (Lajili and Zéghal 2005; Oliveira et al. 2011). In the great majority of research, multivariate analysis is used to understand the associations between the level of risk disclosure, in general, captured by manual content analysis of the annual reports, and different factors potentially affecting the disclosure of risk information by firms. The set of variables-determinants of the risk disclosure - varies between different authors and their approach to the analysis and the importance given to its specific fields.

Many empirical analyses confirm a positive significant relation between company size and risk disclosures indexes Abraham and Cox 2007; Amran et al. 2009; Atan et al. 2010; Beretta and Bozzolan 2004; Dobler et al. 2011; Mohobbot 2005; Linsley and Shrives 2006; Oliveira et al. 2011). However, corporate risk disclosures seem not to be influenced by companies' profitability (Lajili and Zéghal 2005; Mohobbot 2005). In reference to industry, the research presented mixed conclusions with studies showing no association (Abraham and Cox 2007; Atan et al. 2010; Beretta and Bozzolan 2004) and others indicating its existence (Amran et al. 2009; Hassan 2009; Rajab and Schachler 2009).

Consistent with previous research, investors believe that risk management disclosure is important to their portfolio investment decisions (Solomon et al. 2000, 2011). However, many of the latest studies confirm that, generally, companies have been reluctant to provide information about their risk management process (Leopizzi et al. 2020). Outside parties could use the potentially damaging information for their interest (Cormier et al. 2005). Therefore, managers have a difficult trade-off between secrecy and transparency (Leopizzi et al. 2020).

\subsection{Risk Disclosure - In Financial or Non-Financial Reporting}

Until recently, risk disclosures in Europe and Australasia have been largely voluntary (e.g., Buckby et al. 2015; Miihkinen 2012). There is evidence (Elshandidy et al. 2015) that voluntary and mandatory risk disclosure can complement each other, supporting the findings of Bagnoli and Watts (2007) and Einhorn (2005) in this regard. While taking part in the discussion of whether risk disclosure should be in the form of mandatory or voluntary disclosure, Solomon (1999) found that UK institutional investors were demanding more information about how companies manage their risks than was currently being disclosed 
in annual reports. In further research, Solomon et al. (2000) proved that UK institutional investors rely on corporate reports as a key source of risk information, preferring the voluntary format. Elshandidy et al. (2018b), almost two decades later, underline: "Maintaining a system of informative voluntary disclosure has benefits and costs. Potential benefits include, but are not limited to, (i) enhanced credibility and improved investor relations, (ii) access to more liquid markets, (iii) improved pricing and decision-making capabilities, (iv) a reduction in perceived risk, increased reputations, and a lower cost of capital, and (v) reduced litigation risk. Potential costs might include (i) competitive disadvantage if sensitive information is disclosed, (ii) bargaining weaknesses related to stakeholders, (iii) increased litigation risk, and (iv) preparation and audit costs".

In practice, risk disclosures remain largely voluntary, despite the stringency of risk disclosure regulations, due to subjectivity in firms' risks and uncertainties assessments (e.g., Hope et al. 2016; SEC 2010). However, the informativeness of such disclosures is largely unknown (Kravet and Muslu 2013). Moreover, there is a lack of studies concerning voluntary risk disclosure in non-financial reports (Cheung et al. 2010). Khlif and Hussainey (2016), as well as Drees and Heugens (2013), indicate that the narrative content analysis present in the existing research (e.g., of Abdullah et al. 2015; Domínguez and Gámez 2014; Abraham and Cox 2007; Linsley and Shrives 2006) might be vulnerable due to biased representations of a literature body and might lead to false inferences. Therefore, more studies are needed in this field, especially concerning NFD.

There have been many calls to reduce asymmetries in access to corporate information and improve the measurement and disclosure of risk issues, both through financial and non-financial disclosure (Szegö 2002; Beretta and Bozzolan 2004; Mohobbot 2005). Such calls have been prompted by the inadequacy of risk reporting practices (Solomon et al. 2000). The information needs of investors are essential because their assessment of the risks and opportunities of companies will affect share prices and thus the prospects and bonuses of managers (Ulupui et al. 2020). Maximizing financial returns and minimizing risk remains the priority of investors. Where companies do not disclose the information necessary to fully assess risks and returns, both in business and in the social and environmental field, investors protect themselves by assuming the worst-case scenario, what we call adverse selection (Terblanche and De Villiers 2019). To amend the regulations of financial disclosure on risk information, in the era of non-financial reporting and IR gaining momentum, there is also a significant portion of standards and recommendations that refer to risk in non-financial disclosure.

\subsection{Risk in Non-Financial Disclosure-Standards and Formal Requirements}

Unlike financial risk disclosures, which are regulated and often required to be disclosed by regulators, there are no specific binding detailed requirements designed for non-financial risk information published through non-financial disclosure. However, we may find focus on the necessity of risk information disclosure introduced to the standards and recommendations on non-financial reporting, such as CSR/sustainability reporting or integrated reporting. The only exception is the Directive that introduces the first regulations concerning the legal requirements on the non-financial information to be presented by certain companies. Concerning the area of risk, the European Parliament, in its resolution of 6 February 2013, recognized the importance of companies disclosing sustainability information, such as social and environmental factors, to identify sustainability risks and increase investor and consumer confidence (Leopizzi et al. 2020). The tangible effect of it was the Directive (European Union 2014) implementation. Through this Directive, risk management disclosure has become mandatory in many countries (Leopizzi et al. 2020). This Directive obliges "all large public-interest companies, known as undertakings, which are European listed companies, banks and insurers with more than 500 employees, to disclose a statement related to, as a minimum: environmental, social and employee matters; respect for human rights; anti-corruption and bribery matters and diversity on company boards. The Directive requires among other issues the disclosure of principal risks relating 
to matters linked to the undertaking's operations, including its business relationships and products or services that are likely to cause adverse impacts in those areas and how the undertaking is managing those risks" (Directive, European Union 2014). It is expected that the switch from voluntary to mandatory non-financial information thanks to the adoption of the Directive should enhance the quality of disclosed risk-related information and the usefulness of non-financial risk disclosure for investors (Veltri 2020).

Apart from these rules, companies may voluntarily complement the financial statements with the satellite reports on CSR/sustainability matters. There are no binding legal requirements for their content, however, following the best practices, while preparing these reports, companies may base them on the standards and recommendations issued by different organizations. Some of the most important and most frequently used in practice are standards proposed by the Global Reporting Initiative (GRI). The standards issued by the GRI in 2021 state that "the objective of sustainability reporting using the GRI Sustainability Reporting Standards (GRI Standards) is to provide transparency on how an organization contributes or aims to contribute to sustainable development" (GRI 2021). The application of GRI Standards allows an organization to disclose its most substantial impacts on the economy, environment, and people, comprising impacts on their human rights and how the organization manages these impacts. The idea behind their application is the enhancement of transparency on the organization's impacts and increased organizational accountability. As underlined in GRI Standards, investors should be able to use the reported information to identify risks and opportunities related to the organization's impacts and to assess its long-term success. GRI Standards focus on the necessity to disclose the information that is material. They do not refer directly to the risk topics and risk information content. However, while discussing the materiality, GRI Standards highlight that the material topics and impacts should "provide crucial input for identifying financial risks and opportunities related to the organization's impacts, and for financial valuation" (GRI Material Topics 2021). GRI Standards also explain that "the combination of the severity and the likelihood of a negative impact can be referred to as 'risk'. The assessment of the significance of the impacts can be included within broader enterprise risk management systems, provided that these systems assess the impacts the organization has on the economy, the environment, and people, in addition to assessing risks for the organization itself" (GRI Material Topics 2021). In section GRI 201 concerning economic performance, there is, however, a clear reference to risk disclosure. This part of the GRI Standards regulates disclosure concerning four themes (GRI 2021):

- $\quad$ "direct economic value generated and distributed,

- financial implications and other risks and opportunities due to climate change,

- defined benefit plan obligations and other retirement plans and finally,

- financial assistance received from the government".

Only in reference to the disclosure on climate change are there specified requirements on risk disclosure. As climate change presents risks and opportunities to organizations, to their investors, and other stakeholders, they shall report risks and opportunities posed by climate change that have the potential to generate substantive changes in operations, revenue, or expenditure, including (Truant et al. 2017):

- "a description of the risk or opportunity and its classification as either physical, regulatory, or other;

- a description of the impact associated with the risk or opportunity;

- the financial implications of the risk or opportunity before action is taken;

- $\quad$ the methods used to manage the risk or opportunity;

- the costs of actions taken to manage the risk or opportunity".

Another set of requirements concerning non-financial risk disclosure is proposed by the International Integrated Reporting Framework (IIRF) Committee. One of the Integrated Reporting project goals is the broader disclosure of risk that is of interest to a range of stakeholders. According to IIRF (2021), an integrated report should include eight Content 
Elements that are fundamentally linked to each other and are not mutually exclusive. One of them explicitly refers to risks and opportunities disclosure, stating that the company should publish the specific risks and opportunities affecting the organization's ability to create value over the short, medium, and long term and how the organization is dealing with them. This framework states that an integrated report is expected to identify "the key risks and opportunities that are specific to the organization, embracing those that relate to the organization's effects on, and the continued availability, quality, and affordability of, relevant capitals in the short, medium and long term" (IIRF 2021). IIR Framework states that this can include identifying (IIRF 2021):

- "The specific source of risks and opportunities can be internal, external or, commonly, a mix of the two.

- External sources include those stemming from the external environment. Significant factors affecting the external environment include aspects of the legal, commercial, social, environmental and political context that affect the organization's ability to create value in the short, medium or long term. They can affect the organization directly or indirectly (e.g., by influencing the availability, quality and affordability of a capital that the organization uses or affects). Internal sources include those stemming from the organization's business activities. Key of them include: how the organization differentiates itself in the marketplace (e.g., through product differentiation, market segmentation, delivery channels and marketing); the extent to which the business model relies on revenue generation after the initial point of sale (e.g., extended warranty arrangements or network usage charges); how the organization approaches the need to innovate; how the business model has been designed to adapt to change, initiatives such as process improvement, employee training and relationships management.

- The organization's assessment of the likelihood that the risk or opportunity will come to fruition and the magnitude of its effect if it does. This includes consideration of the specific circumstances that would cause the risk or opportunity to come to fruition. Such disclosure will invariably involve a degree of uncertainty.

- The specific steps being taken to mitigate or manage key risks or to create value from key opportunities, including the identification of the associated strategic objectives, strategies, policies, targets and key performance indicators".

In the framework, it is clearly stated that "considering the principle of materiality, the organization's approach to any real risks (whether they be in the short, medium or long term) that are fundamental to the ongoing ability of the organization to create value and that could have extreme consequences should be ordinarily included in an integrated report, even when the probability of their occurrence might be considered quite small" (IIRF 2021, p. 44). As de Villiers et al. (2014) highlighted, risks and opportunities ought to be a critical part of disclosure in IR practices. However, as noticed by Szczepankiewicz (2021), "the risk identification in integrated reports can be performed on the basis of the financial part of the report (annual financial statement) and the company's activity report, as well as other risks that the company wants to disclose. The components of the annual financial statements do not disclose risks related to the company's business environment, operations of the company and its capital group, capital market and secondary stock market, management and measurement of intangibles (intellectual capital), CSR activity. Therefore, the key risk factors in the said areas should be addressed in the non-financial part of the integrated report".

Based on the literature review presented in this section, we arrive at the formulation of two research questions.

RQ 1: What are the topics related to risk included in the non-financial disclosure of companies listed on the WSE? 
RQ 2: What influenced the risk topics ratio in the non-financial disclosure of companies listed on the WSE?

\section{Materials and Methods}

\subsection{Sample and Data Collection}

Consistent with the premises from the literature review in our paper, to answer our research questions, as a first step, we prepared the list of the WSE companies (excluding banks and investments funds) that, following the Directive 2014/95/UE, were obliged to prepare NFD in 2018. We decided to investigate NFD in the second year of the Directive's implementation, assuming that companies were already familiar enough with the new obligations of NFD. We also considered 2018 as a good starting point for future trends analysis in NFD risk information. We identified 149 companies on the WSE that met our criteria. At the end of 2020, by searching the WSE Electronic Information Transmission System and Electronic Information Base through www.stockwatch.pl, accessed on 10 December 2020, (STOCKWATCH.PL 2021), and companies' websites, we collected all available NFDs for the fiscal year of 2018. We created a set of NFD documents (corpus) for 126 companies. To prepare our corpus for textual analysis, we conducted a series of activities to clean documents of all types of infographics and spelling errors. For each document, we collected information about NFD reporting standards (GRI Standards, based on GRI Standards, nonGRI Standards, such as Polish Standards for Non-Financial Information, Polish Accounting Act, own rules) and the type of NFD (as a part of MD\&A, Non-Financial Information (NFI) Report, CSR Report, Sustainability Report, Integrated Report). Using the EMIS database and WSE Yearbook for 2018 (WSE 2019), we gathered companies' financial and industry data. Table 1 presents the characteristics of our sample.

Table 1. Characteristics of the sample.

\begin{tabular}{|c|c|c|c|c|c|}
\hline \multicolumn{2}{|l|}{ Information Category } & $\mathrm{N}$ & & & \\
\hline \multicolumn{2}{|l|}{ All } & 126 & & & \\
\hline \multirow{8}{*}{ Industry } & Finance & 3 & & & \\
\hline & Oil \& Energy & 9 & & & \\
\hline & Chemicals \& Materials & 18 & & & \\
\hline & Industrials & 43 & & & \\
\hline & Consumer Goods & 27 & & & \\
\hline & Trade \& Services & 13 & & & \\
\hline & Health Care & 5 & & & \\
\hline & Technology & 8 & & & \\
\hline \multirow{3}{*}{ NFD Standard } & non-GRI & 68 & & & \\
\hline & GRI & 38 & & & \\
\hline & based on GRI & 20 & & & \\
\hline \multirow{4}{*}{ Disclosure Type } & MD\&A Part & 57 & & & \\
\hline & NFI Report & 50 & & & \\
\hline & CSR/Sustainability Report & 11 & & & \\
\hline & Integrated Report & 8 & & & \\
\hline Statistic Measure & Mean & Median & Min & Max & St. Dev. \\
\hline $\begin{array}{l}\text { Total Assets (in } \\
\text { thousands of EURO) }\end{array}$ & $680,200.83$ & 219,904 & 1582.80 & $8,660,000$ & $1,494,638.67$ \\
\hline $\begin{array}{l}\text { ROA (Net } \\
\text { Income/Assets) }\end{array}$ & $2.53 \%$ & $3.40 \%$ & $-53.33 \%$ & $89.92 \%$ & 0.12 \\
\hline Leverage (Debt/Equity) & 1.51 & 16.85 & -6.60 & 10.68 & 1.84 \\
\hline No of Employees & 4395.22 & 1685 & 214 & 41,231 & 7212.24 \\
\hline Age & 40 & 28 & 10 & 142 & 28.32 \\
\hline
\end{tabular}

To give a complete understanding of the sample, in Table 1 we present the basic information, including financial characteristics of the researched companies. As the Directive refers the non-financial disclosure obligation of all large public-interest entities, known as 
undertakings, which are European listed companies, our sample consists of big companies with an average number of full-time employees of around 4400 and a total value of assets of around EUR 680 million. The average company age (40 years) indicates that we investigate entities with a long business history (taking into consideration the political system change in Poland, which took place in 1989). As the majority of companies are well-established organizations from traditional sectors, their average leverage ratio (the mean value of debt to equity ratio equals 1.51) is relatively high, while average profitability (the mean value of the return of assets ratio equals $2.53 \%$ ) stays low.

\subsection{Methodology}

To find out the risk topics and their distribution in NFD (RQ 1), we applied a topic modeling analysis. Topic models are computer algorithms that use the distribution of words in the analyzed corpus to identify latent patterns of words' co-occurrence (Jacobi et al. 2016). Lately, a tool often used for topic modeling is an unsupervised Bayesian machine learning approach called latent Dirichlet allocation (LDA), introduced by Blei, $\mathrm{Ng}$, and Jordan (Blei et al. 2003). It is still recognized as a cutting-edge method (Jacobi et al. 2016) that has recently become more frequently used in companies' financial and non-financial reporting studies (Hadro et al. 2021; Dyer et al. 2017; Brown et al. 2020; Huang et al. 2018). The authors of the method explain that LDA is a generative probabilistic model of a corpus. The basic idea is that documents are represented as random mixtures over latent topics, where each topic is characterized by a distribution over words (Blei et al. 2003, p. 996).

We used multilingual topic modeling (MTM) - one of the tools developed within CLARIN-PL (Walkowiak and Malak 2018)_which is a Polish research consortium and a section of pan-European Common Language Resources and Technology Infrastructure (CLARIN) (http:/ / clarin-pl.eu/en/what-is-clarin; accessed on 10 September 2021, CLARIN-PL 2021). The LDA analysis outputs from MTM are the list of the 30 most frequent keywords with their frequency for each of the topics selected and the probability of topic relevance for each document (as LDA is a probabilistic measure) understood as a concentration of topics across the corpus. The ratio of a topic's alpha divided by the sum of all topic alphas measures the share of the topic in the corpus (Jaworska and Nanda 2018). Although LDA is a machine learning approach excluding researcher biases in most of the topic modeling process, two operations required research decisions: choosing the number of topics in a corpus and topic labeling concerning the most frequent keywords. We resolved the first issue by iteration-running LDA by increasing the number of topics right to the moment that they do not overlap each other. Overlapped topics have a large share of common co-occurring words (Goloshchapova et al. 2019). To verify the overlapping of the topics, we used an intertopic distance map (one of the MTM functionalities), a two-dimensional graphical presentation of LDA analysis achieved using multidimensional scaling-principal component analysis (PCA). For our corpus, we reached the optimum at 21 topics. For the second issue, looking at the NFD standard, we developed a list with topics that could appear in NFD. Using cross-checking between two researchers and looking at the ten most frequent words (Hadro et al. 2021; Goloshchapova et al. 2019), we labeled LDA topics with NFD ones. We identified risk topics, assuming that a topic belongs to risk topics if the root of word risk appears among the ten most frequent words. As LDA does not recognize synonyms and hyponyms, we merged topics with the same information issues and concepts. Following the approach of Jaworska and Nanda (2018), we merged topics that had the same labels, subsequently verifying their similarities by cross-checking lists of the most frequent co-occurring words for each merged topic. In the case of risk topics, we had three topics labeled as Health $\mathcal{E}$ Safety Policy and two topics labeled as Social Policy. Regarding the first topic group, the most frequent words had very similar meanings, such as work, safety, accident, procedure, policy. For the second group the most frequent words also represent the same thematic issues: employee, social, policy, ethics, program. Finally, we obtained 15 topics for further analysis. 
As our next step, we run a cluster analysis to understand whether, among companies listed on the WSE, there are common patterns in communicating risk information in NFD. We expected that there is a possibility to identify groups (clusters) in which companies show similarity in the risk topic mixture. The variables that we used for clustering were the LDA risk topics alphas. Cluster analysis is a well-established method to discover hidden patterns in multivariate data (Kettenring 2006), and is also applied in disclosure strategies studies. We used Ward's method as it has several advantages. First, in Ward's algorithms, as in all hierarchical methods, the number of groups (clusters) is established after analysis (Humphries et al. 2007; Saraçli et al. 2013). Second, as Ward declares, his desire was to "minimize the loss associated with each grouping and to quantify that loss in a form that could be readily interpreted" (Ward 1963, p. 236). By "loss", he meant the loss in information resulting from treating a group of observations as one by calculating their mean of values. He proposed the error sum of squares as a "value-reflecting" number (Ward 1963). In his algorithm to merge a new pair of clusters, the sum of squares deviation from a new cluster centroid has to be calculated. A pair of clusters is merged, with a minimal increase in the error sum of squares (Majerova and Nevima 2017). Minimizing the increase in the error sums of squares at each stage of that analysis allows minimizing heterogeneity and obtaining clusters with the greatest similarity, which is the principle of the Ward method and a desirable feature for our investigation. Finally, Punj and Stewart (1983) and Saraçli et al. (2013), among other academics, elaborate on the comparison of cluster analysis methods based on the literature review. Authors investigating research publications regarding results of empirical testing with different cluster algorithms but applied to the same data sets indicate that Ward's minimum variance method outperformed other cluster methods, taking into consideration a set of accuracy measures. We studied cluster dendrograms visually to identify the number of clusters. We are aware of that approach's limitations; still, as studies show, it is one of the most frequent solutions chosen by academics (Ketchen and Shook 1996; Saraçli et al. 2013; Schonlau 2004). Figure 1 presents our Ward's cluster dendrogram - a treelike structure. Each leaf represents a company as a starting cluster. Similar clusters (the closest ones) are connected into relations (branches), which are new aggregate clusters reducing the number of overall clusters. Eventually, all relationships are grouped into one large cluster. The vertical (height) axis presents the value of the total within-cluster error sum of squares, which increases going up the tree and makes the clusters more numerous but less homogenous. The height of the cut to the dendrogram indicates the number of clusters. Our dendrogram indicates to cut it at the height of five, resulting in four clusters. Finally, we applied ANOVA to confirm the significant differences in topic alphas among Ward's clusters.

To answer RQ 2, we searched for the variables that influenced the risk topics ratio in NFD. We used the results of topic modeling analysis to calculate the variable Risk Topics Ratio and literature review (Sections 2.1 and 2.3) to define independent variables. Our model is as follows:

$$
\begin{gathered}
\text { Risk Topics Ratio }=f(G R I \text { Standard, CSR Report, High EES Risk Industry, Size, } \\
\text { Profitability), }
\end{gathered}
$$

where:

Risk Topics Ratio is a dependent variable representing the risks topics share in an NFD, calculated as the sum of risk topics alpha divided by the sum of all topics alpha for each NFD document;

GRI Standard is a variable that divides our sample into three groups: NFD prepared according to GRI Standard, NFD based on GRI Standard, NFD prepared according to non-GRI Standard (Polish Standards for Non-Financial Information, Polish Accounting Act, companies' own rules);

CSR Report is a dichotomy variable that takes 1 when NFD is prepared as a document separated from an annual report (NFI Report, CSR Report, Sustainability Report, Integrated Report) and 0 when NFD is included as a part of MD\&A; 
High EES Risk Industry is a dichotomy variable that takes 1 when a company operates in an industry that is recognized to have high environmental or social risk and 0 otherwise. We followed the European Bank for Reconstruction and Development guidance, which indicates oil, gas, and forestry sectors as having high environmental risk and the mining sector as having high social risk;

Size is a variable that indicates the size of a company measured as the natural log of the company's total assets;

Profitability is a variable that indicates the profitability of a company measured as a return on assets (ROA): net income over total assets.

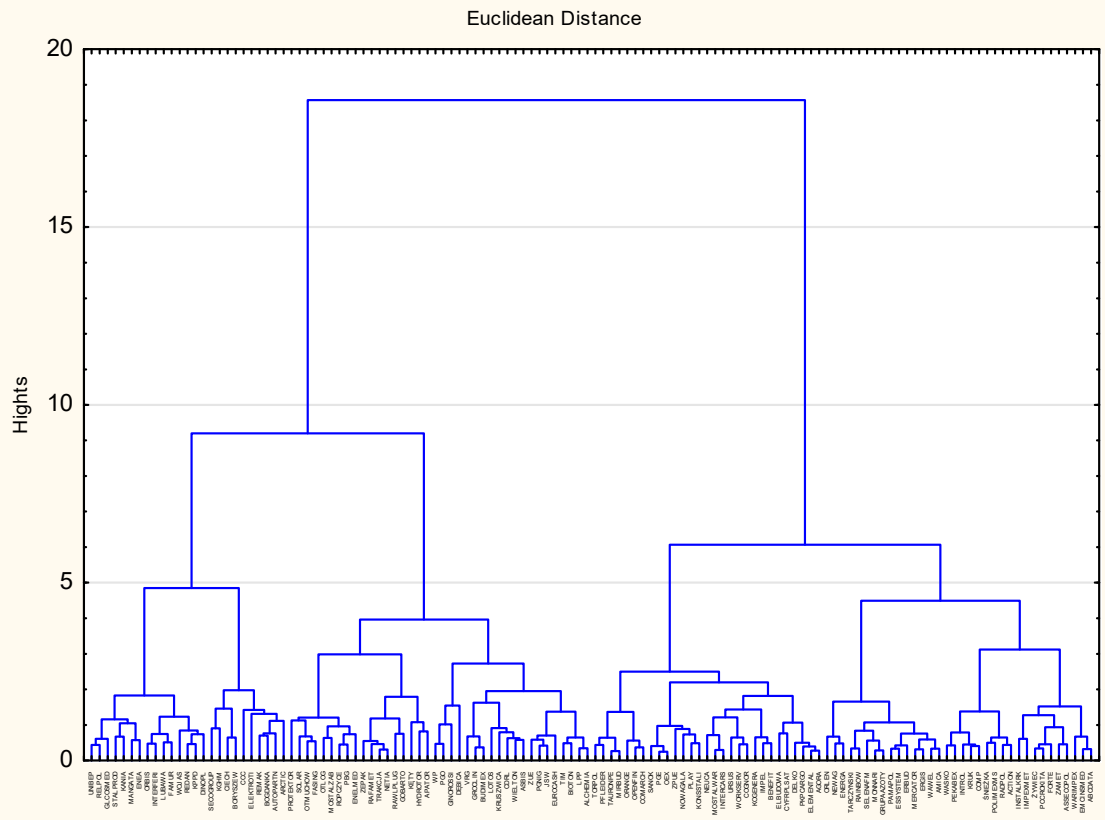

Figure 1. Ward's cluster dendrogram. Source: own work using STATISTICA software.

To overcome the limitations of the many grouping variables in our model and a relatively small sample, we applied qualitative comparative analysis (QCA). QCA is a settheoretic method applying Boolean algebra rules. It uses sets and searches for set relations to form concepts and formulate casual relations between social phenomena (Schneider and Wagemann 2012). Ragin first presented QCA in 1987 (Ragin 1987), and it was initially predominately used in sociology and political science and is still rarely used among scholars (Seny Kan et al. 2016). Lately, it has become more frequently explored in business and management studies (Cucari 2019; Wagemann et al. 2016), developing a new wave of "neo-configurational" research (Greckhamer et al. 2018).

Among many advantages of QCA over traditional statistical and econometric techniques, at least two reflect the more adequate holistic vision of an organization and its environment. The first one assumes that combinations (solutions, configurations) of factors (variables), which form patterns or profiles rather than individual independent variables, lead to an outcome (also referring to conjunctural causation in set theory) (Schneider and Wagemann 2012). The second means that the set-theoric perspective notices the existence of equifinality understood as alternative factors that can produce the same outcome (Schneider and Wagemann 2012). Usually, statistical analysis is unifinally oriented (Wagemann et al. 2016), which contrasts with organizational reality, where much often more than one causal condition explains a specific outcome (Fainshmidt et al. 2020). QCA distinguishes between necessary and sufficient conditions for an outcome. Necessary conditions have to be present for an outcome to occur. There cannot be any outcome without the necessary conditions. A sufficient but not necessary condition allows the existence of other sufficient 
conditions for the same outcome, which indicates the existence of equifinality in QCA (Schneider and Wagemann 2012).

Set-theoretic methods operate on membership scores of elements in sets (Schneider and Wagemann 2012). There are two types of variables-crisp sets variables, which are natural dichotomies variables, where 1 signifies full membership in a set and 0 full nonmembership in a set, and fuzzy sets variables, which are non-dichotomy variables. If a variable is a dichotomy by its nature, it belongs to a crisp set. In the case of non-dichotomy, the first step in QCA analysis is the calibration of the degree of membership in a set.

In our model, we had both types of variables. CSR Report and High EES Risk Industry are crisp set variables, while GRI Standard, Risk Topics Ratio, Size, and Profitability are fuzzy set variables. For fuzzy set variables, we used the following calibration methods:

- $\quad$ for the variable GRI Standard, we coded 1 if NFD was prepared according to GRI Standards, 0.5 if NFD was based on GRI Standards, and 0 if NFD was prepared according to non-GRI Standards (Polish Standards for Non-Financial Information, Polish Accounting Act, own rules);

- for variables Risk Topics Ratio, Size, and Profitability we applied the fuzzy set direct calibration method (Ragin 2007).

After calibration, we ran our model with fs/QCA software (downloaded from http: //compasss.org/software/; accessed on 10 August 2020). The QCA uses the QuineMcCluskey algorithm with the simplification rules of Boolean expressions to determine configurations for an outcome (Fiss 2007; Schneider and Wagemann 2012). Finally, the QCA results are presented as models of sufficient and necessary condition configurations, along with the degree of two metrics:

- consistency - the degree to which solution terms and the solution as a whole are subsets of the outcome (Rihoux and Ragin 2008):

$$
\text { Consistency }\left(X_{i} \leq Y_{i}\right)=\frac{\sum\left(\min \left(X_{i}, Y_{i}\right)\right.}{\sum\left(X_{i}\right)}
$$

- coverage-numeric expression for the empirical importance (sufficiency) and relevance (necessity) of a given condition (or a combination) for producing an outcome (Schneider and Wagemann 2012):

$$
\text { Coverage }\left(X_{i} \leq Y_{i}\right)=\frac{\sum\left(\min \left(X_{i}, Y_{i}\right)\right.}{\sum\left(Y_{i}\right)}
$$

In Equations (2) and (3), min indicates the selection of the lower of two values, $X_{i}$ represents membership scores in a combination of conditions, and $Y_{i}$ represents membership scores in the outcome. The consistency and coverage are evaluated for each configuration (combination/solution) and for each model as a whole. In the case of coverage, there is a distinction among (Schneider and Wagemann 2012): solution coverage, which indicates how much of the outcome is covered by the entire solution term, raw coverage, which indicates how much of the outcome is covered by each of the combinations (paths), and unique coverage, which indicates how much of the outcome is covered only by a specific combination (path).

In QCA, the are three levels of model results: a parsimonious solution, with fundamental conditions for a model, and an intermediate solution, which is a subset of a parsimonious solution and a superset of a complex solution (the third possible solution). We choose to focus on the parsimonious solution as it presents core elements that cannot be eliminated and must be part of any solution giving a clear answer of what are the necessary configurations for an outcome to appear. The parsimonious solution gives paths of variables' combinations that indicate strong relations with an outcome and, unlike in the other solutions, are less sensitive to errors (Fiss 2007; Maggetti and Levi-Faur 2013). In our 
case, intermediate and complex solutions are the same and differ from parsimonious ones with only one path, with very low unique coverage.

\section{Results and Discussion}

Figure 2 presents the results of LDA-the distribution of 15 topics present in the WSE companies' NFDs. Eight are identified as non-risk topics. The most frequent non-risk topics are Products $\mathcal{E}$ Services (14\%) and Strategy $\mathcal{E}$ Values (10\%). Among all eight non-risk topics, only four relate directly to the environmental, social and governmental issues: Waste Management/Circular Economy (5\%), Energy Management (5\%), Stakeholders' Communication $(5 \%)$, Social Policy (5\%). That indicates that companies devote the majority of NFD space to general information unrelated to ESG issues.

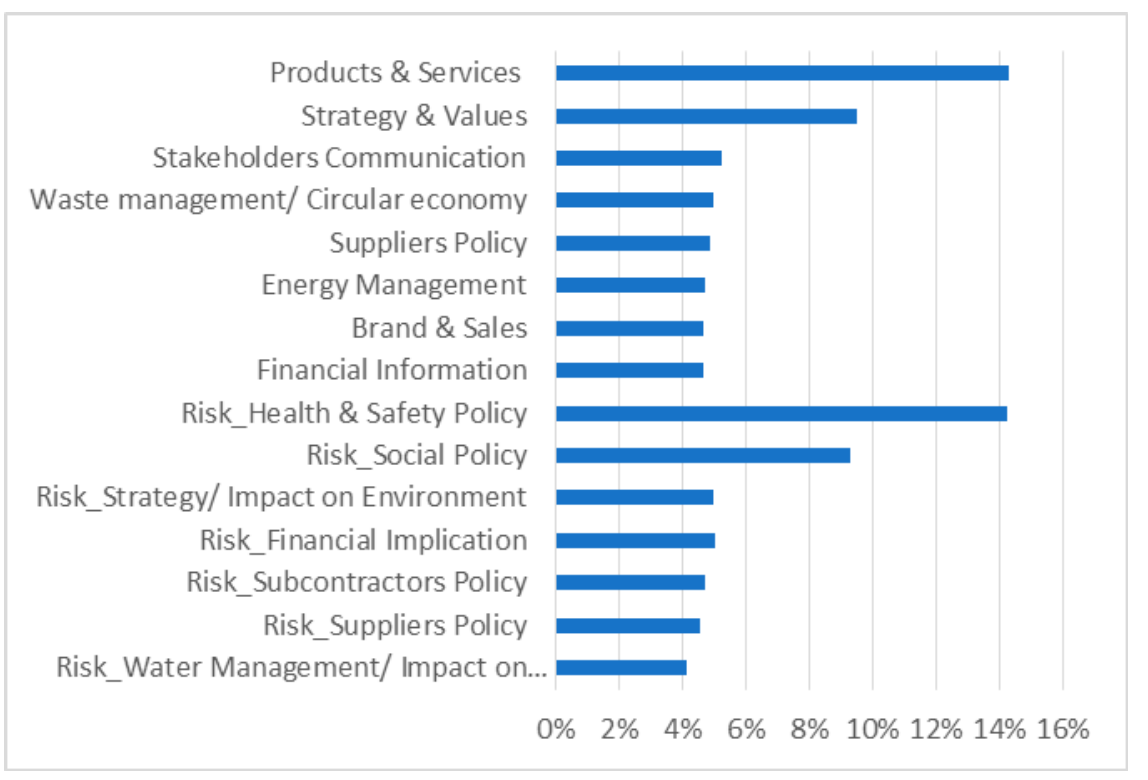

Figure 2. Distribution of non-financial disclosure topics-LDA results. Source: own work with CLARIN MTM.

As the first step in answering RQ 1, we identified seven risk topics, consisting of $47 \%$ of all latent topics in our corpus (Figure 2). Among risk topics (Table 2), the most frequent ones are those related to social risk. The aggregate social risk topics' share in our sample equals 70\%. Among them, Health $\mathcal{E}$ Safety Policy and Social Policy are the most extensively reported as they cover over $50 \%$ of all space in NFD dedicated to risk information. However, the variety of social risk topics is very limited. Companies are unwilling to communicate about the risk of human rights and workforce diversity violation or social risk to the local community.

Substantially less space is devoted to environmental risk. There are only two topics that consist of $20 \%$ of the total risk topics share: Strategy/Impact on Environment and Water Management/Impact on Environment. The results show that companies, despite the relevance of environmental risk issues, are very selective in disclosing information on that matter. Surprisingly, they avoid talking about very appealing subjects of interest to various groups of stakeholders, such as energy risk, waste risk, raw materials risk, or biodiversity risk. In Financial Implication, companies publish information of only a qualitative nature. That topic constitutes $10 \%$ of all risk topics shares. 
Table 2. Risk topics with ten most frequent words and topic share.

\begin{tabular}{|c|c|c|}
\hline Risk Topic & Ten Most Frequent Words within a Topic & Topic Share \\
\hline Health \& Safety Policy & $\begin{array}{l}\text { Employee, protection, social, risk, procedure, } \\
\text { safety, accident, policy, human, hazard }\end{array}$ & $30.17 \%$ \\
\hline Social Policy & $\begin{array}{l}\text { Employee, labor, activity, risk, environment, social, } \\
\text { compliance, policy, ethics, protection }\end{array}$ & $20.08 \%$ \\
\hline Strategy/Impact on environment & $\begin{array}{l}\text { Production, mining, safety, metal, principle, } \\
\text { design, risk, strategy, value, global }\end{array}$ & $10.67 \%$ \\
\hline Financial Implication & $\begin{array}{l}\text { Service, financial, risk, customer, network, result, } \\
\text { management, operational, cost, obligation }\end{array}$ & $10.39 \%$ \\
\hline Subcontractors' Policy & $\begin{array}{l}\text { Construction, realization, investment, work, risk, } \\
\text { project, agreement, contract, service, subcontractor }\end{array}$ & $10.09 \%$ \\
\hline Suppliers' Policy & $\begin{array}{l}\text { Product, work, system, employee, supplier, risk, } \\
\text { indicator, market, client, ethics }\end{array}$ & $9.73 \%$ \\
\hline $\begin{array}{c}\text { Water management/Impact on } \\
\text { environment }\end{array}$ & $\begin{array}{l}\text { Activity, segment, environment, water, protection, } \\
\text { production, metal, chemical, operation, risk }\end{array}$ & $8.87 \%$ \\
\hline
\end{tabular}

Source: own work with CLARIN MTM.

Table 3 shows the distribution of the topics' mixture for each of four identified Ward's clusters. Companies from Cluster 1 (cluster with the smallest number of companies-25) disclose the most information related to risk in their NFD, concentrated predominantly on two social risk topics: Health $\mathcal{E}$ Safety and Suppliers' Policy. They do not dedicate much space to Subcontractors' Policy and Water Management/Impact on Environment. The most numerous is Cluster 2, with 38 companies included. In that cluster, two social risk topics (Social Policy, Subcontractors' Policy) and two environmental risk topics (Strategy/Impact on Environment, Water Management/Impact on Environment) are the longest among all clusters. In Cluster 3, very little space is devoted to social risk topics, especially to Social Policy, Subcontractors' Policy, and Suppliers' Policy and also to the topic Water Management/Impact on Environment. The largest cluster (34 companies), but with the shortest risk disclosure, is Cluster 4. However, companies here talk relatively much about social risk in two topics (Social Policy, Subcontractors' Policy), environmental risk (Water Management/Impact on Environment), and Financial Implication of risk. The lowest mean value of the Health $\mathcal{E}$ Safety risk topic and Strategy/Impact on Environment belongs to that cluster.

Table 3. ANOVA results for risk topic clusters.

\begin{tabular}{|c|c|c|c|c|c|c|}
\hline \multirow[b]{2}{*}{ Risk Topic } & \multicolumn{5}{|c|}{ Mean Values of Risk Topic Alpha } & \multirow[b]{2}{*}{$p$-Value } \\
\hline & All & Cluster 1 & Cluster 2 & Cluster 3 & Cluster 4 & \\
\hline Health \& Safety Policy & 1.24 & 1.96 & 1.28 & 1.16 & 0.71 & $* * *$ \\
\hline Social Policy & 0.82 & 0.86 & 1.11 & 0.48 & 0.75 & $* * *$ \\
\hline $\begin{array}{l}\text { Strategy/Impact on } \\
\text { Environment }\end{array}$ & 0.44 & 0.49 & 0.62 & 0.38 & 0.23 & ** \\
\hline Financial Implication & 0.43 & 0.49 & 0.45 & 0.33 & 0.42 & * \\
\hline Subcontractors' Policy & 0.41 & 0.39 & 0.49 & 0.37 & 0.37 & \\
\hline Suppliers' Policy & 0.40 & 0.55 & 0.43 & 0.30 & 0.32 & $* * *$ \\
\hline $\begin{array}{l}\text { Water Management/Impact } \\
\text { on Environment }\end{array}$ & 0.36 & 0.35 & 0.44 & 0.28 & 0.34 & ** \\
\hline Sum & 4.10 & 5.09 & 4.82 & 3.30 & 3.14 & $* * *$ \\
\hline No. of Companies & 126 & 25 & 38 & 29 & 34 & \\
\hline
\end{tabular}

Cluster analysis results suggest that companies disclosing risk information extensively in their NFDs concentrate almost solely on social risk matters. In contrast, companies 
talking briefly about E\&S risk prepare their NFDs with a more balanced distribution of environmental and social topics and their financial implication.

Tables 4 and 5 and Figure 3 present results of a set of analyses to answer RQ 2. Looking at the mean values of the risk topics ratio (Table 4), companies from low E\&S risk industries disclose more risk information ( $48.29 \%$ of NFD) than those from high E\&S risk ones $(46.61 \%$ of NFD). The shortest risk disclosure is prepared while using GRI Standards ( $47.55 \%$ of NFD), but the longest ones use GRI Standards selectively (47.87\% of NFD). Separate reports have, on average, longer risk parts ( $47.83 \%$ of NFD) than those included in annual reports as a part of MD\&A ( $45.91 \%$ of NFD).

Table 4. Risk topics ratio descriptive statistics.

\begin{tabular}{cccccc}
\hline \multicolumn{2}{c}{ Risk Topics Ratio } & N & Mean & Variance & St. Dev. \\
\hline \multirow{2}{*}{ Industry } & All & 126 & 0.4694 & 0.0041 & 0.0642 \\
\cline { 2 - 5 } & With high E\&S risk & 26 & 0.4661 & 0.0048 & 0.0694 \\
\cline { 2 - 5 } & With low E\&S risk & 100 & 0.4829 & 0.0040 & 0.0628 \\
\cline { 2 - 6 } NFD Standard & Non-GRI & 68 & 0.4755 & 0.0037 & 0.0609 \\
\cline { 2 - 5 } & GRI & 38 & 0.4543 & 0.0053 & 0.0729 \\
\cline { 2 - 6 } & Based on GRI & 20 & 0.4787 & 0.0031 & 0.0558 \\
\hline \multirow{2}{*}{ Disclosure Type } & MD\&A part & 57 & 0.4591 & 0.0045 & 0.0673 \\
\cline { 2 - 5 } & CSR report & 69 & 0.4783 & 0.0037 & 0.0609 \\
\hline
\end{tabular}

Source: own work with STATISTICA software.

Table 5 presents the results of the necessary analysis for the outcome Risk Topics Ratiothe first step in analyzing QCA results. For all variables, the value of coverage metrics is lower than 0.9 , which means that there is no single factor (variable) included in the model that explains by itself a high level of Risk Topics Ratio. That result indicates running further steps in QCA with sufficient conditions (Allen and Allen 2015).

Table 5. Analysis of QCA necessary conditions.

\begin{tabular}{ccc}
\hline Variable & Consistency & Coverage \\
\hline GRI Standard & 0.40 & 0.47 \\
CSR Report & 0.57 & 0.47 \\
High E\&S Risk Industry & 0.20 & 0.45 \\
Size & 0.74 & 0.66 \\
Profitability & 0.78 & 0.73 \\
\hline
\end{tabular}

Source: own work with fs/software.

The combinations of sufficient conditions are presented as a diagram (Figure 3) (Rubinson 2019). Out of 32 possible logical combinations of variables (factors/conditions), we received three solutions that led to a high level of Risk Topics Ratio. Not all variables are included in our solutions as conditions, which means they are not relevant for the outcome. Solution 1 indicates that companies with high E\&S risk publish extensive risk information in their NFDs when choosing to disclose in annual reports as part of MD\&A following non-GRI standards (companies' size and profitability in that configuration are not relevant). In Solution 2, there are low E\&S risk companies with high profitability, which prepare separate CSR reports (CSR/sustainability reports or integrated reports). The NFD standard type is not included in that configuration. The last solution (Solution 3) includes big companies with low profitability, whose NFDs are presented as CSR reports prepared with non-GRI standards. Belonging to high or low E\&S risk industries is not relevant for that configuration.

The results of QCA underline that there is more than one logical explanation for a high level of Risk Topics Ratio in NFD. In general, in most cases, exposure to E\&S risk 
matters in risk disclosure. Surprisingly, GRI Standards are not a guarantee for extensive risk disclosure. Still, separate CSR reports are more likely to have more space devoted to risk information, especially when accompanied by non-GRI standards.

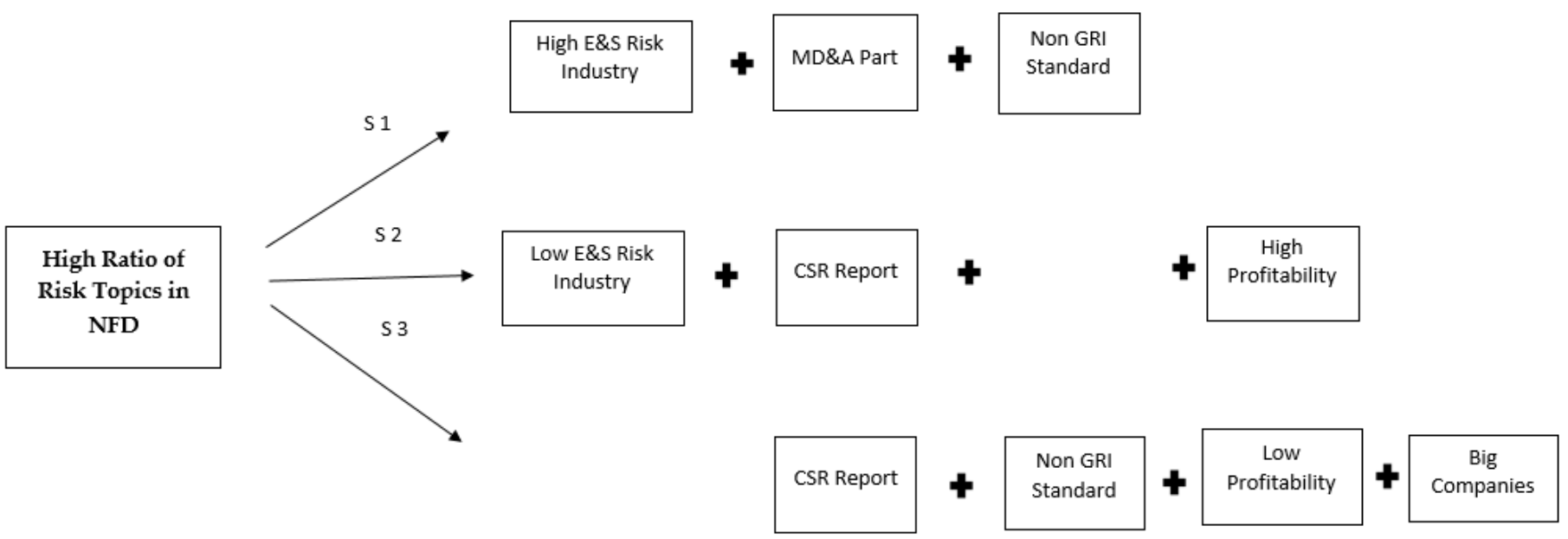

Figure 3. Diagram of QCA results for high ratio of risk topics model. Source: own work with $\mathrm{fs}$ /software. Blank space means that a variable is not relevant for a solution. S1 represents Solution 1; S2, Solution 2; and S3, Solution 3, respectively. Solution 1: raw coverage 0.09, unique coverage 0.09, consistency 0.67 ; Solution 2 : raw coverage 0.38 , unique coverage 0.19 , consistency 0.81 ; Solution 3 : raw coverage 0.21 , unique coverage 0.03 , consistency 0.79 . Model coverage 0.50 . Model consistency 0.76 .

\section{Conclusions}

Stakeholders, particularly investors, need useful risk information to help them understand the company's risk profiles. Disclosure practice should focus on providing useful decision-making information to support investors in identifying sources of risk. A lack of informed investors and access to inaccurate risk information can lead to uncertainty and poor decisions with serious financial repercussions. Therefore, risk disclosure should play an important role in the companies' communication with stakeholders. This is also understood by the regulators and standard setters that directlyor indirectly impose or encourage this information disclosure on companies, as well as in non-financial disclosure. However, the degree of accuracy and subject matter of this type of disclosure indicated by the regulators and standard setters of NFD vary. Our research results also proved that the level of involvement of the companies in risk disclosure in NFD differs.

This paper contributes to the existing literature that relates to risk information and its disclosure. We researched the topics related to risk included in NFD of companies listed on the Warsaw Stock Exchange and the determinants influencing the risk topics ratio in NFD. We also identified homogenous groups of risk topic mixtures of companies.

Our results confirmed that companies disclose risk information extensively in their NFDs, almost half of all the information that the analyzed companies communicate to their stakeholders in non-financial disclosure refers to risk topics. In general, the companies' exposure to E\&S risk, NFD standards, and the type of non-financial reporting where risk information is disclosed impact the space dedicated to risk information.

Although the amount of risk disclosure is substantial, we found out that the risk information disclosed is very selective when analyzing the risk topics disclosed and their context. Companies usually disclose topics that refer to social risks. This is surely caused by the legal requirements that strictly regulate occupational safety and health procedures and rules. Therefore, companies that have to introduce them into their operations are willing and able to write about them extensively in the social risk information. Eventually, those companies also implement information concerning subcontractors' and suppliers' risk information; nevertheless, all these are still the topics of the social risk group of information. Other topic areas relating to other types of risk tend to receive superficial treatment or are 
ignored altogether. This conclusion refers mainly to those companies that disclose extensive and far-reaching information about risk. At the same time, they limit themselves mainly to social risk information release. In contrast, companies talking briefly about risk prepare their NFDs with a more balanced distribution of E\&S topics, and they also usually publish the financial implications of risk exposure.

Our survey results challenge the methodology that assumes one should evaluate disclosure by looking at the volume of information regarding non-financial disclosure, including risk. To make an appropriate assessment, one must focus on the information content, the breadth of the disclosure, and the context of risk information published.

The risk aspect of the non-financial disclosure standards and guidelines can impact companies by encouraging them to include negative and disappointing stories in addition to predictable positive disclosures in a more balanced way. The results of our study may become of great importance to the standard setters and regulators. Our findings indicate that risk disclosure, even though extensive, should be less selective, more balanced, and should address all areas and all types of risk more comprehensively. Therefore, the potential focus for standard setters and regulators should be on creating recommendations, guidelines, and standards that would address the issues of risk disclosure in a more direct and complex way. Those organizations should consider deeply clarifying and detailing the requirements and provide the direction and guidance on how to present risk issues more comprehensively. It would also be advisable to make risk disclosure recommendations dependent on the company's industry. At the same time, companies should put more effort into satisfying their stakeholders that expect more balanced information on risk while using NFD in their decision processes.

Our study also showed that the extent of risk reporting depends on the guidelines and standards a company uses to prepare its NFD. Those companies that prepared their NFDs based on guidelines other than GRI presented more diverse and balanced risk information. The analysis of the recommendations showed that GRI Standards treat risk in a rather general and non-direct way. Although it was not a case in our sample, it is generally the most widely used set of guidelines for publishing non-financial information worldwide (www.globalreporting.org; accessed on 12 December 2021). Therefore, it might be worth considering a greater and more precise specification, especially of the GRI Standards, for a more comprehensive multidimensional risk disclosure. From our research, it is shown that as risk is important in companies' operations, GRI Standards should give it more space and attention to facilitate and boost its disclosure.

This research has numerous empirical contributions that could be of interest to academics and standard setters. It contributes to filling the gap in research about risk disclosure in NFD, identifying the main topics of corporate risk disclosures and groups of homogenous risk topics mixtures of companies. It also brings up-to-date results about the determinants of risk disclosure in NFD, namely the industry, standards followed, and the source of non-financial disclosure.

We believe that our research contributes to the risk literature in giving a more complete picture of the current state of play in a voluntary engagement of companies in this field. We contribute to the existing research on risk disclosure by providing new evidence on the extent to which and how merging the accounting numbers is significant for reflecting a more complete picture of companies' risk. Our paper also advances prior research on the determinants of risk disclosure and gives an insight to the regulators that may inspire themselves to make the necessary changes in the recommendations they promote. Regulators should be interested in these results as they point to the importance of narrative risk disclosures and thus are consistent with the call for more forward-looking risk disclosures by companies.

The important contribution of this study is also the methodology and tools applied in the analysis. It provides a unique empirical insight into the disclosure research using sophisticated machine learning tools instead of the traditional approaches that are commonly 
adopted in academic papers, and at the same time, it presents the application of qualitative comparative analysis in companies' reporting research for causal reasoning.

However, the findings of this study should be interpreted with caution because of the limitations concerning the one-country analysis, one-year time period, and focus on only listed companies.

Given the potential role of risk disclosure in reducing information asymmetries between a company and different groups of market participation, it would be valuable to conduct future research to establish other countries' and other groups of companies' practices concerning risk disclosure. Additionally, other determinants of disclosure can be a subject of future research. The prospective analysis should also focus on the relational connectivity between the information disclosed and the concrete information needs of a particular group of stakeholders and consequently on the level of their satisfaction concerning the information that they are provided with.

Author Contributions: Conceptualization, J.F. and D.H.; Formal analysis, Justyna Fijałkowka D.H.; Methodology, J.F. and D.H.; Software, D.H.; Literature Review, J.F., Writing-original draft, J.F. and D.H.; Writing-review \& editing, J.F. and D.H. All authors have read and agreed to the published version of the manuscript.

Funding: The project is financed by the Ministry of Science and Higher Education in Poland under the programme "Regional Initiative of Excellence" 2019-2022 project number 015/RID/2018/19 total funding amount 10721 040,00 PLN.

Institutional Review Board Statement: Not applicable.

Informed Consent Statement: Not applicable.

Data Availability Statement: Not applicable.

Conflicts of Interest: The authors declare no conflict of interest.

\section{References}

Abdullah, Maizatulakma Zaleha Abdul Shukor, Zakiah Muhammadun Mohamed, and Azlina Ahmad. 2015. Risk Management Disclosure: A Study on the Effect of Voluntary Risk Management Disclosure toward Firm Value. Journal of Applied Accounting Research 16: 400-32. [CrossRef]

Abraham, Santhosh, and Paul Cox. 2007. Analysing the Determinants of Narrative Risk Information in UK FTSE 100 Annual Reports. The British Accounting Review British Accounting Review 39: 227-48. [CrossRef]

Abraham, Santhosh, and Philip J. Shrives. 2014. Improving the Relevance of Risk Factor Disclosure in Corporate Annual Reports. The British Accounting Review 46: 91-107. [CrossRef]

Ahmed, Anwer S., Anne Beatty, and Bruce Bettinghus. 2004. Evidence on the efficiency of interest rate risk disclosures by commercial banks. The International Journal of Accounting 39: 223-51. [CrossRef]

American Institute of Certified Public Accountants (AICPA). 1987. Report of the Task Force on Risks and Incertainties. New York: American Institute of Certified Public Accountants.

American Institute of Certified Public Accountants (AICPA). 1994. Improving business reporting. In A Customer Focus. New York: American Institute of Certified Public Accountants.

Allen, Matthew M. C., and Maria L. Allen. 2015. Companies Access to Finance, Co-Operative Industrial Relations, and Economic Growth: A Comparative Analysis of the States of South Eastern Europe. Research in International Business and Finance 33: 167-77. [CrossRef]

Allini, Alessandra, Manes Rossi Francesca, and Hussainey Khaled. 2016. The Board's Role in Risk Disclosure: An Exploratory Study of Italian Listed State-Owned Enterprises. Public Money and Management 36: 113-20. [CrossRef]

Amran, Azlan, Abdul Manaf Rosli Bin, and Bin Che Haat Mohd Hassan. 2009. Risk reporting: An exploratory study on risk management disclosure in Malaysian annual reports. Managerial Auditing Journal 24: 39-57. [CrossRef]

Atan, Ruhaya, Nurdin Enny Sutan Marahun, Wan Abdul Kadir Wan Hasnah, and Jusoff Kamaruzaman. 2010. Annual Risk Reporting of Listed Companies in Malaysia. Journal of Modern Accounting and Auditing 6: 26-38.

Bagnoli, Mark, and Susan G. Watts. 2007. Financial reporting and supplemental voluntary disclosures. Journal of Accounting Research 45: 885-913. [CrossRef]

Bakos, Levente, and Dănut Dumitru Dumitrașcu. 2021. Decentralized enterprise risk management issues under rapidly changing environments. Risks 9: 165. [CrossRef]

Bao, Yang, and Anindya Datta. 2014. Simultaneously discovering and quantifying risk types from textual risk disclosures. Management Science 60: 1371-91. [CrossRef] 
Barth, Mary E., and Wayne R. Landsman. 2010. How Did Financial Reporting Contribute to the Financial Crisis? European Accounting Review 19: 399-423. [CrossRef]

Bartoszewicz, Anna, and Anna Rutkowska-Ziarko. 2021. Practice of Non-Financial Reports Assurance Services in the Polish Audit Market-The Range, Limits and Prospects for the Future. Risks 9: 176. [CrossRef]

Beretta, Sergio, and Saverio Bozzolan. 2004. A framework for the analysis of firm risk communication. International Journal of Accounting 39: 265-88. [CrossRef]

Blei, David M., Andrew Y. Ng, and Michael I. Jordan. 2003. Latent Dirichlet Allocation. Journal of Machine Learning Research 3: $993-1022$.

Bravo, Franciso. 2017. Are Risk Disclosures an Effective Tool to Increase Firm Value? Managerial and Decision Economics 38: 1116-24. [CrossRef]

Brown, Nerissa C., Richard M. Crowley, and W. Brooke Elliott. 2020. What Are You Saying? Using Topic to Detect Financial Misreporting. Journal of Accounting Research 58: 237-91. [CrossRef]

Buckby, Sherrena, Gerry Gallery, and Jiacheng Ma. 2015. An analysis of risk management disclosures: Australian evidence. Managerial Auditing Journal 30: 812-69. [CrossRef]

Cabedo, J. David, and José Miguel Tirado. 2004. The disclosure of risk in financial statements. Accounting Forum 28: 181-200. [CrossRef]

Campbell, John L., Hsinchun Chen, Dan S. Dhaliwal, Hsin-Min Lu, and Logan B. Steele. 2014. The information content of mandatory risk factor disclosures in corporate filings. Review of Accounting Studies 19: 396-455. [CrossRef]

Chen, Jennifer C., Dennis M. Patten, and Robin W. Roberts. 2008. Corporate charitable contributions: A corporate social performance or legitimacy strategy? Journal of Business Ethics 82: 131-44. [CrossRef]

Cheung, Yan-Leung, Ping Jiang, and W. Weiqiang Tan. 2010. A Transparency Disclosure Index Measuring Disclosures: Chinese Listed Companies. Journal of Accounting Public Policy 29: 259-80. [CrossRef]

CLARIN-PL. 2021. Available online: http:/ / clarin-pl.eu/en/what-is-clarin (accessed on 10 September 2021).

Cole, Cathy J., and Christopher L. Jones. 2004. The usefulness of MD \& A disclosure in the retail industry. Journal of Accounting, Auditing and Finance 9: 361-88.

Cormier, Denis, Michel Magnan, and Barbara Van Velthoven. 2005. Environmental dis- closure quality in large German companies: Economic incentives, public pressures or institutional conditions? The European Accounting Review 14: 3-39. [CrossRef]

Cucari, Nicola. 2019. Qualitative Comparative Analysis in Corporate Governance Research: A Systematic Literature Review of Applications. Corporate Governance: The International Journal of Business in Society 19: 717-34. [CrossRef]

de Villiers, Charl, Leonardo Rinaldi, and Jeffrey Unerman. 2014. Integrated reporting: Insights, gaps and an agenda for future research. Accounting, Auditing and Accountability Journal 27: 1042-67. [CrossRef]

Deegan, Craig. 2000. Financial Accounting Theory. Sydney: McGraw-Hill Book Company.

Deegan, Craig. 2002. Introduction: The legitimising effect of social and environmental disclosures-A theoretical foundation. Accounting, Auditing \& Accountability Journal 15: 282-311.

Deegan, Craig, Michaela Rankin, and John Tobin. 2002. An examination of the corporate social and environmental disclosures BHP from 1983-97: A test of legitimacy theory. Accounting, Auditing and Accountability Journal 15: 312-43. [CrossRef]

Deloitte. 2021. Reporting of Non-Financial Information. Available online: https://www2.deloitte.com/content/dam/Deloitte/be/ Documents/audit/DT-BE-reporting-of-non-financial-info.pdf (accessed on 3 November 2021).

Deumes, Rogier. 2008. Corporate Risk Reporting: A Content Analysis of Narrative Risk Disclosures in Prospectuses. Journal of Business Communication 45: 120-57. [CrossRef]

Deumes, Rogier, and W. Robert Knechel. 2008. Economic Incentives for Voluntary Reporting on Internal Risk Management and Control Systems. AUDITING: A Journal of Practice and Theory 27: 35-66. [CrossRef]

Dobler, Michael, Kaouthar Lajili, and Daniel Zéghal. 2011. Attributes of corporate risk disclosure: An international investigation in the manufacturing sector. Journal of International Accounting Research 10: 1-22. [CrossRef]

Domínguez, Luis Rodríguez, and Ligia Carolina Noguera Gámez. 2014. Corporate reporting on risks: Evidence from Spanish companies. Revista de Contabilidad 17: 116-29. [CrossRef]

Drees, Johannes M., and Pursey Heugens. 2013. Synthesising and Extending Resource Dependence Theory: A Meta-Analysis. Journal of Management 39: 1666-98. [CrossRef]

Dyer, Travis, Mark Lang, and Lorien Stice-Lawrence. 2017. The Evolution of 10-K Textual Disclosure: Evidence from Latent Dirichlet Allocation. Journal of Accounting and Economics 64: 221-45. [CrossRef]

Dziwok, Ewa, and Marta Karaś. 2021. Systemic Illiquidity Noise-Based Measure-A Solution for Systemic Liquidity Monitoring in Frontier and Emerging Markets. Risks 9: 124. [CrossRef]

Einhorn, Eti. 2005. The nature of the interaction between mandatory and voluntary disclosures. Journal of Accounting Research 43: 593-621. [CrossRef]

Elamer, Ahmed A., Collins G. Ntim, Hussein A. Abdou, Alaa Mansour Zalata, and Mohamed Elmagrhi. 2019. The impact of multi-layer governance on bank risk disclosure in emerging markets: The case of Middle East and North Africa. Accounting Forum 43: $246-81$. [CrossRef]

Elshandidy, Tamer, Ian Fraser, and Khaled Hussainey. 2015. What drives mandatory and voluntary risk reporting variations across Germany, UK, and US? The British Accounting Review 47: 376-94. [CrossRef]

Elshandidy, Tamer, Lorenzo Neri, and Yingxi Guo. 2018a. Determinants and impacts of risk disclosure quality: Evidence from China. Journal of Applied Accounting Research 19: 518-36. [CrossRef] 
Elshandidy, Tamer, Philip J. Shrives, Matt Bamber, and Santhosh Abraham. 2018b. Risk reporting: A review of the literature and implications for future research. Journal of Accounting Literature 40: 54-82. [CrossRef]

Elzahar, Hany, and Khaled Hussainey. 2012. Determinants of Narrative Risk Disclosures in UK Interim Reports. The Journal of Risk Finance 13: 133-47. [CrossRef]

European Union. 2014. Directive 2014/95/EU. Official Journal of the European Union 214: 1-9.

Fainshmidt, Stav, Michael A. Witt, Ruth V. Aguilera, and Alain Verbeke. 2020. The Contributions of Qualitative Comparative Analysis (QCA) to International Business Research. Journal of International Business Studies 51: 455-66. [CrossRef]

Fijałkowska, Justyna, and Beata Zyznarska-Dworczak. 2018. Sustainability reporting of Polish banks-A step towards greater accountability. Entrepreneurship and Management 19: 47-61.

Fiss, Peer C. 2007. A Set-Theoretic Approach to Organizational Configurations. Academy of Management Review 32: 1180-98. [CrossRef]

Fraczkiewicz-Wronka, Aldona, Tomasz Ingram, Karolina Szymaniec-Mlicka, and Piotr Tworek. 2021. Risk Management and Financial Stability in the Polish Public Hospitals: The Moderating Effect of the Stakeholders' Engagement in the Decision-Making. Risks 9: 87. [CrossRef]

García-Sánchez, Isabel-Maria, Lazaro Rodríguez-Ariza, and Jose-Valeriano Frías-Aceituno. 2013. The cultural system and integrated reporting. International Business Review 22: 828-38. [CrossRef]

Goloshchapova, Irina, Ser-Huang Poon, Matthew Pritchard, and Phil Reed. 2019. Corporate Social Responsibility Reports: Topic Analysis and Big Data Approach. The European Journal of Finance 25: 1637-54. [CrossRef]

Gray, Rob, Reza Kouhy, and Simon Lavers. 1995. Corporate social and environmental reporting: A review of the literature and a longitudinal study of UK disclosure. Accounting, Auditing and Accountability Journal 8: 47-77. [CrossRef]

Greckhamer, Thomas, Santi Furnari, Peer C. Fiss, and Ruth V. Aguilera. 2018. Studying Configurations with Qualitative Comparative Analysis: Best Practices in Strategy and Organization Research. Strategic Organization 16: 482-95. [CrossRef]

GRI. 2021. Full set of GRI Standards 2021. Available online: https:/ / www.globalreporting.org/how-to-use-the-gri-standards/resourcecenter/?g=0d615506-dac0-4f46-b75f-5d9bb3ccc675andid=13673 (accessed on 12 December 2021).

GRI Material Topics. 2021. Available online: https://www.globalreporting.org/media/zauil2g3/public-faqs-universal-standards-_1 -october.pdf (accessed on 12 December 2021).

Guthrie, James, Francesca Manes Rossi, Rebecca Levy Orelli, and Giuseppe Nicolò. 2020. Investigating Risk Disclosures in Italian Integrated Reports. Meditari Accountancy Research 28: 1149-78. [CrossRef]

Hadro, Dominika, Justyna Fijałkowska, Karolina Daszyńska-Żygadło, Ilze Zumente, and Svetlana Mjakuškina. 2021. What Do Stakeholders in the Construction Industry Look for in Non-Financial Disclosure and What Do They Get? Meditari Accountancy Research. Ahead-of-print. [CrossRef]

Hassan, Mostafa Kamal. 2009. UAE Corporations-Specific Characteristics and Level of Risk Disclosure. Managerial Auditing Journal 24: 668-87. [CrossRef]

Healy, Paul M., and Krishna G. Palepu. 2001. Information asymmetry, corporate disclosure, and the capital markets: A review of the empirical disclosure literature. Journal of Accounting and Economics 31: 405-40. [CrossRef]

Heinle, Mirko S., and Kevin C. Smith. 2017. A Theory of Risk Disclosure. Review of Accounting Studies 22: 1459-91. [CrossRef]

Hirschi, Stephan. 2021. Non-financial Reporting: Responsible, far-Sighted Management, PWC. Available online: https:/ /www.pwc. ch/en/insights/disclose/23/non-financial-reporting-responsible-far-sighted-management.htmlv (accessed on 30 October 2021).

Hope, Ole-Kristian, Danqi Hu, and Hai Lu. 2016. The benefits of specific risk-factor disclosures. Review of Accounting Studies 21: 1005-45. [CrossRef]

Huang, Allen H., Reuven Lehavy, Amy Y. Zang, and Rong Zheng. 2018. Analyst Information Discovery and Interpretation Roles: A Topic Modeling Approach. Management Science 64: 2833-55. [CrossRef]

Humphries, Andrew S., John Towriss, and Richard Wilding. 2007. A Taxonomy of Highly Interdependent, Supply Chain Relationships: The Use of Cluster Analysis. The International Journal of Logistics Management 18: 385-401. [CrossRef]

Institute of Chartered Accountants in England and Wales (ICAEW). 2011. Reporting Business Risks: Meeting Expectations. London: Institute of Chartered Accountants of England and Wales. Available online: https://www.icaew.com/ \{\}/media/corporate/ files/technical/financial\%20reporting/information\%20for\%20better\%20markets/ifbm/rbr\%20final.ashx (accessed on 30 October 2021).

International Framework (IIRF). 2021. January. Available online: https:/ /www.integratedreporting.org/wp-content/uploads/2021/0 1/InternationalIntegratedReportingFramework.pdf (accessed on 30 October 2021).

Jackson, Susan T. 2021. Risking Sustainability: Political Risk Culture as Inhibiting Ecology-Centered Sustainability. Risks 9: 186. [CrossRef]

Jacobi, Carina, Wouter van Atteveldt, and Kasper Welbers. 2016. Quantitative Analysis of Large Amounts of Journalistic Texts Using Topic Modelling. Digital Journalism 4: 89-106. [CrossRef]

Jaworska, Sylvia, and Anupam Nanda. 2018. Doing Well by Talking Good: A Topic Modelling-Assisted Discourse Study of Corporate Social Responsibility. Applied Linguistics 39: 373-99. [CrossRef]

Jia, Jing, Lois Munro, and Sherrena Buckby. 2016. A finer-grained approach to assessing the "quality" ("quantity" and "richness") of risk management disclosures. Managerial Auditing Journal 31: 770-803. [CrossRef]

Jorgensen, Bjorn N., and Michael T. Kirschenheiter. 2003. Discretionary risk disclosures. The Accounting Review 78: 449-69. [CrossRef] 
Ketchen, David J., and Christopher L. Shook. 1996. The application of cluster analysis in strategic management research: An analysis and critique. Strategic Management Journal 17: 441-58. [CrossRef]

Kettenring, Jon R. 2006. The Practice of Cluster Analysis. Journal of Classification 23: 3-30. [CrossRef]

Khlif, Hichem, and Khaled Hussainey. 2016. The association between risk disclosure and firm characteristics: A meta-analysis. Journal of Risk Research 19: 181-211. [CrossRef]

Kravet, T., and V. Muslu. 2013. Textual risk disclosures and investors risk perceptions. Review of Accounting Studies 18: 1088-122. [CrossRef]

Lajili, Kaouthar, and Daniel Zéghal. 2005. A content analysis of risk management disclosure in Canadian annual reports. Canadian Journal of Administrative Sciences 22: 125-42. [CrossRef]

Lehavy, Reuven, Feng Li, and Kenneth Merkley. 2011. The effect of annual report readability on analyst following and the properties of their earnings forecasts. The Accounting Review 86: 1087-115. [CrossRef]

Leopizzi, Rossella, Antonio Iazzi, Andrea Venturelli, and Salvatore Principale. 2020. Nonfinancial Risk Disclosure: The "State of the Art" of Italian Companies. Corporate Social Responsibility and Environmental Management 27: 358-68. [CrossRef]

Linsley, Philip M., and Michael J. Lawrence. 2007. Risk reporting by the largest UK companies: Readability and lack of obfuscation. Accounting, Auditing and Accountability Journal 20: 620-27. [CrossRef]

Linsley, Philip, and Philip Shrives. 2000. Risk Management and Reporting Risk in the UK. Journal of Risk 3: 115-29. [CrossRef]

Linsley, Philip, and Philip Shrives. 2005. Transparency and the Disclosure of Risk Information in the Banking Sector. Journal of Financial Regulation and Compliance 13: 205-14. [CrossRef]

Linsley, Philip M., and Philip J. Shrives. 2006. Risk Reporting: A Study of Risk Disclosures in the Annual Reports of UK Companies. The British Accounting Review 38: 387-404. [CrossRef]

Linsley, Philip M., Philip Shrives, and P. Kajuter. 2008. Risk reporting: Development, regulation and current practice. In International Risk Management: Systems, Internal Control and Corporate Governance. Edited by Margaret Woods, Peter Kajuter and Philip Linsley. London: Elsevier, pp. 185-207.

Linsmeier, Thomas J., Daniel B. Thornton, Mohan Venkatachalam, and Michael Welker. 2002. The effect of mandated market risk disclosures on trading volume sensitivity to interest rate, exchange rate, and commodity price movements. The Accounting Review 77: 343-77. [CrossRef]

Lukason, Oliver, and María-del-Mar Camacho-Miñano. 2019. Bankruptcy Risk, Its Financial Determinants and Reporting Delays: Do Managers Have Anything to Hide? Risks 7: 77. [CrossRef]

Lyle, Matthew R., Jeffrey L. Callen, and Robert J. Elliott. 2013. Dynamic risk, accounting-based valuation and firm fundamentals. Review of Accounting Studies 18: 899-929. [CrossRef]

Maggetti, Martino, and David Levi-Faur. 2013. Dealing with errors in QCA. Political Research Quarterly 2013: 198-204.

Magnan, Michel, and Garen Markarian. 2011. Accounting, governance and the crisis: Is risk the missing link? European Accounting Review 20: 215-31. [CrossRef]

Majerova, Ingrid, and Jan Nevima. 2017. The measurement of human development using the Ward method of cluster analysis. Journal of International Studies 10: 239-57. [CrossRef]

Merkl-Davies, Doris M., Niamh M. Brennan, and Stuart J. McLeay. 2011. Impression Management and Retrospective Sense-Making in Corporate Narratives: A Social Psychology Perspective. Accounting, Auditing and Accountability Journal 24: 315-44. [CrossRef]

Miihkinen, Antti. 2012. What drives quality of firm risk disclosure?: The impact of a national disclosure standard and reporting incentives under IFRS. The International Journal of Accounting 47: 437-468. [CrossRef]

Miihkinen, Antti. 2013. The usefulness of firm risk disclosures under different firm riskiness, investor interest, and market conditions: New evidence from Finland. Advances in Accounting, Incorporating Advances in International Accounting 29: 312-31. [CrossRef]

Mohobbot, Ali. 2005. Corporate Risk Reporting Practices in Annual Reports of Japanese Companies. Japanese Journal of Accounting 16: 113-33.

Moolman, Jaco, Merwe Oberholzer, and Maxi Steyn. 2016. The effect of integrated reporting on integrated thinking between risk, opportunity and strategy and the disclosure of risks and opportunities. Southern African Business Review 20: 600-27. [CrossRef]

Oliveira, Jonas, Lúcia Lima Rodrigues, and Russell Craig. 2011. Risk-related disclosures by non-finance companies: Portuguese practices and disclosure characteristics. Managerial Auditing Journal. [CrossRef]

Pérignon, Christophe, and Daniel R. Smith. 2010. The level and quality of Value-at-Risk disclosure by commercial banks. Journal of Banking and Finance 34: 362-77. [CrossRef]

Punj, Girish, and David W. Stewart. 1983. Cluster analysis in marketing research: Review and suggestions for application. Journal of Marketing Research 20: 134-48. [CrossRef]

Ragin, Charles C. 1987. The Comparative Method: Moving Beyond Qualitative and Quantitative Strategies. Berkley: University of California Press.

Ragin, Charles C. 2007. Fuzzy Sets: Calibration versus Measurement. Methodology Volume of Oxford Handbooks of Political Science. Oxford: Oxford University, p. 2.

Rajab, Bassam, and Morrison Handley Schachler. 2009. Corporate Risk Disclosure by UK Firms: Trends and Determinants. World Review of Entrepreneurship, Management and Sustainable Development 5: 224. [CrossRef]

Rajgopal, Shivaram. 1999. The Risk Management of Everything: Rethinking the Politics of Uncertainty. London: Demos. 
Rihoux, Benoît, and Charles C. Ragin. 2008. Configurational Comparative Methods: Qualitative Comparative Analysis (QCA) and Related Techniques. London: SAGE Publications.

Rubinson, Claude. 2019. Presenting Qualitative Comparative Analysis: Notation, Tabular Layout, and Visualization. Methodological Innovations 12: 205979911986211. [CrossRef]

Saraçli, Sinan, Nurhan Doğan, and İsmet Doğan. 2013. Comparison of Hierarchical Cluster Analysis Methods by Cophenetic Correlation. Journal of Inequalities and Applications 2013: 203. [CrossRef]

Schneider, Carsten Q., and Claudius Wagemann. 2012. Set-Theoretic Methods for the Social Sciences: A Guide to Qualitative Comparative Analysis. Cambridge: Cambridge University Press.

Schonlau, Matthias. 2004. Visualizing non-hierarchical and hierarchical cluster analyses with clustergrams. Computational Statistics 19: 95-111. [CrossRef]

Schrand, Catherine M., and John A. Elliott. 1998. Risk and Financial Reporting: A Summary of the Discussion at the 1997 AAA/FASB Conference. Accounting Horizons 12: 271-82.

Securities and Exchange Commission (SEC). 2010. 17 CFR parts 211, 231 and 241 com-Mission Guidance Regarding Disclosure Related to Climate Change. Washington, DC: SEC.

Seny Kan, Anderson Konan, Emmanuel Adegbite, Sami El Omari, and Mahamat Abdellatif. 2016. On the Use of Qualitative Comparative Analysis in Management. Journal of Business Research 69: 1458-63. [CrossRef]

Serrasqueiro, Rogério Marques, and Tânia Sofia Mineiro. 2018. Corporate Risk Reporting: Analysis of Risk Disclosures in the Interim Reports of Public Portuguese Non-Financial Companies. Contaduria y Administracion 63: 1-15. [CrossRef]

Sheraz, Muhammad, and Imran Nasir. 2021. Information-Theoretic Measures and Modeling Stock Market Volatility: A Comparative Approach. Risks 9: 89. [CrossRef]

Shivaani, M. V., P. K. Jain, and Surendra S. Yadav. 2019. Development of a risk disclosure index and its application in an Indian context. Managerial Auditing Journal 35: 1-23. [CrossRef]

Singleton-Green, Brian. 2012. Commentary: Financial reporting and financial stability: Causes and effects. Australian Accounting Review 22: 15-17. [CrossRef]

Solomon, Jill Frances. 1999. Do institutional investors in the UK adopt a dual strategy for managing foreign exchange risk? The British Accounting Review 31: 205-24. [CrossRef]

Solomon, Morton B., and Joe R. Cooper. 1990. Reporting on Internal Control: The SEC's Proposed Rules. Journal of Accountancy 169: 56.

Solomon, Jill Frances, Aris Solomon, Simon D. Norton, and Nathan L. Joseph. 2000. A conceptual framework for corporate risk disclosure emerging from the agenda for corporate governance reform. The British Accounting Review 32: 447-78. [CrossRef]

Solomon, Jill Frances, Aris Solomon, Simon D. Norton, and Nathan. L. Joseph. 2011. Private climate change reporting: An emerging discourse of risk and opportunity? Accounting, Auditing and Accountability Journal 24: 1119-48. [CrossRef]

Steurer, Reinhard. 2010. The role of governments in corporate social responsibility: Characterising public policies on CSR in Europe. Policy Sciences 43: 49-72. [CrossRef]

Steurer, R. 2015. CSR and governments: Public policies on CSR in Europe. Corporate Social Responsibility 2015: 240.

Steyn, Maxi. 2014. Organisational benefits and implementation challenges of mandatory integrated reporting: Perspectives of senior executives at South African listed companies. Sustainability Accounting, Management and Policy Journal 5: 476-503. [CrossRef]

STOCKWATCH.PL. 2021. Available online: www.stockwatch.pl (accessed on 10 December 2021).

Sundgren, Stefan, Juha Mäki, and Antonio Somoza-López. 2018. Analyst coverage, market liquidity and disclosure quality: A study of fair-value disclosures by European real estate companies under IAS 40 and IFRS 13. The International Journal of Accounting 53: 54-75. [CrossRef]

Szczepankiewicz, Elżbieta I. 2011. Selected issues in effective implementation of the integrated risk management system in an organization. Zeszyty Naukowe Uniwersytetu Szczecińskiego. Finanse, Rynki Finansowe, Ubezpieczenia 49: 153-62.

Szczepankiewicz, Elzbieta I. 2021. Identification of Going-Concern Risks in CSR and Integrated Reports of Polish Companies from the Construction and Property Development Sector. Risks 9: 85. [CrossRef]

Szegö, Giorgio. 2002. Measure of risk. Journal of Banking and Finance 26: 1253-72. [CrossRef]

Tan, Youchao, Cheng Colin Zeng, and Tamer Elshandidy. 2017. Risk disclosures, international orientation, and share price informativeness: Evidence from China. Journal of International Accounting, Auditing and Taxation 29: 81-102. [CrossRef]

Terblanche, Wendy, and Charl De Villiers. 2019. The influence of integrated reporting and internationalization on intellectual capital disclosures. Journal of Intellectual Capital 20: 40-59. [CrossRef]

Tirado-Beltrán, Jose Miguel, J. David Cabedo, and Dennis Esther Muñoz-Ramírez. 2020. Risk Disclosure and Cost of Equity: A Bayesian Approach. Revista CEA 6: 25-43. [CrossRef]

Truant, Elisa, Laura Corazza, and Simone Scagnelli. 2017. Sustainability and Risk Disclosure: An Exploratory Study on Sustainability Reports. Sustainability 9: 636. [CrossRef]

Ulupui, Igka, Yunika Murdayanti, Muhammad Yusuf, Indra Pahala, and Adam Zakaria. 2020. Integrated Reporting Disclosure and Its Implications on Investor Reactions. The Journal of Asian Finance, Economics, and Business 7: 433-44. [CrossRef]

Vandemaele, Sigrid, Philip Vergauwen, and A. Michels. 2009. Management Risk Reporting Practices and Their Determinants: A Study of Belgian Listed Firms. Available online: http:/ /hdl.handle.net/1942/9392 (accessed on 10 September 2021).

Veltri, Stefania. 2020. Mandatory Non-Financial Risk-Related Disclosure. Berlin/Heidelberg: Springer. 
Venkatachalam, Mohan. 1996. Value-relevance of banks' derivative disclosures. Journal of Accounting and Economics 22: 327-55. [CrossRef]

Venturelli, Andrea, Fabio Caputo, Rossella Leopizzi, and Simone Pizzi. 2019. The State of Art of Corporate Social Disclosure before the Introduction of Non-Financial Reporting Directive: A Cross Country Analysis. Social Responsibility Journal 15: 409-23. [CrossRef]

Verrecchia, Robert E. 1983. Discretionary disclosure. Journal of Accounting and Economics 5: 179-94. [CrossRef]

Wagemann, Claudius, Jonas Buche, and Markus B. Siewert. 2016. QCA and Business Research: Work in Progress or a Consolidated Agenda? Elsevier Enhanced Reader. Journal of Business Research 69: 2531-40. [CrossRef]

Walkowiak, Tomasz, and Piotr Malak. 2018. Polish Texts Topic Classification Evaluation. Paper presented at 10th International Conference on Agents and Artificial Intelligence, Madeira, Portugal, January 16-18; Portugal: SCITEPRESS-Science and Technology Publications, pp. 515-22. [CrossRef]

Ward, Joe H., Jr. 1963. Hierarchical grouping to optimize an objective function. Journal of the American Statistical Association 58: 236-44. [CrossRef]

Wong, Anson. 2013. Corporate sustainability through non-financial risk management. International Journal of Business Management 14: 575-66. [CrossRef]

WSE. 2019. WSE Yearbook for 2018, Warsaw Stock Exchange. Available online: www.gpw.pl (accessed on 10 December 2021). 